\title{
Evaluation of Different Carrier Materials for Development of Bacterial Bio- Control Agents Formulations with Enhanced Shelf-Life
}

\author{
S.M. Jayasudha", K.C. Kirankumar, Eranna Rajashekhara and Rudresh \\ Department of Plant Pathology, College of Horticulture, Bagalkot University of Horticultural \\ sciences, Bagalkot- 587103, Karnataka, India \\ *Corresponding author
}

\section{A B S T R A C T}

The environmental pollution and risk of resistance development in the pathogen by the use of chemical pesticide makes necessary to use biological agents. However the major

Keywords

Bacterial

bio-agents,

Carrier material,

Formulation,

Shelf life.

Article Info

Accepted:

17 July 2017

Available Online:

10 September 2017 limitations to utilize biological agents are the inconsistency, unreliable efficacy and short shelf life of the living entities used in the formulation. In this context an experiment was conducted to formulate four bacterial bio-agents viz., Bacillus subtilis-KK-9A, Brevibacillus borstelensis-BK-6, Brevibacillus sp-PM-2A and Lysinibacillus xylanilyticusVK-6B and consortium of them. Seven carrier materials viz., bentonate, kaolin, perlite, phytosil, talc, vermiculite and zeolite were used and studied the shelf life of bio-agents in this carrier material up to 90 days. Among seven carrier materials vermiculite recorded the highest number of colonies of all the four bio-agents and consortium when checked at fifteen days interval up to three months. This is followed by zeolite, kaolin, perlite, talc, bentonite and phytosil in the order of their efficacy. Further the highest survival \% (21.6, $46.3,30.3,28.2$ and 32.1) of all the four bio-agents and consortium respectively was observed in vermiculite based formulation. However, least survival percentage of Bacillus subtilis-KK-9A (3.7), Brevibacillus borstelensis-BK-6(3.15), Brevibacillus sp-PM-2A (3.7) and Lysinibacillus xylanilyticus- VK-6B (10.1) and consortium (2.9) was recorded in phytosil based formulation at $90^{\text {th }}$ day.

\section{Introduction}

The extensive usage of chemical fertilizers and pesticides for increasing productivity and production led to health hazards and environmental pollution. The use of biofertilizers and bio-pesticides has been advocated as a safe substitute for sustaining high production with low environmental impact (Hermosa et al., 2012).

Biological management of plant pathogen by antagonistic microorganisms is a potential non chemical means (Harman, 1991) and is known to be a cheap and effective, ecofriendly method for management of crop disease (Cook and Baker, 1983). Some of the bio-control agents like Bacillus subtillis and Pseudomonas fluorescence exhibit inhibition zone and found antagonistic to Xanthomonas axonopodis pv. punicae (Yenjerappa et al., 2013). In this context biological management of plant pathogen by antagonistic microorganisms is taking upper hand. However they also recorded the inconsistency and unreliable efficacy due to their shorter life 
compared to chemical pesticides. By focusing this problem current research has been conducted on formulation and shelf-life of four bio-agents (Bacillus subtilis-KK-9A, Brevibacillus borstelensis-BK-6, Brevibacillus sp-PM-2A and Lysinibacillus xylanilyticus- VK-6B) and consortium which were found effective against the bacterial blight of pomegranate (Ippikoppa, 2015) by using different carrier materials.

\section{Materials and Methods}

\section{Bacterial bio-agents}

Four bacterial biocontrol agents viz., Bacillus subtilis-KK-9A, Brevibacillus borstelensisBK-6, Brevibacillus sp-PM-2A and Lysinibacillus xylanilyticus- VK-6B were collected from Department of Plant pathology, $\mathrm{COH}$, Bagalkot. These cultures were collected from pomegranate rhizosphere and maintained by the earlier worker and reported their effectiveness against X.a.p causing bacterial blight of pomegranate. The cultures were recovered on AK agar no. 2 and preserved for further use.

Efficacy of bacterial bio-agents against X.a.p by agar well diffusion method

The efficacy of these bio-agents were reconfirmed by agar well method it involves making of nutrient broth and before pour into petriplates add X.a.p culture into it, after solidification, an agar plate is punched asepectically with sterile cork borer and volume of the $(20-100 \mu \mathrm{l})$ of culture filtrate is introduced into well. Then, the culture filtrate of each bio-agent can be poured into well and it was incubated at $30^{\circ} \mathrm{C}$ for $48 \mathrm{hr}$.

\section{Carrier materials used}

The inert solid carriers used in the formulations are Bentonate, Kaolin, Perlite, Phytosil, Talc, Vermiculite and Zeolite. The carrier materials were collected from different sources and also their physico-chemical properties were tested and the details are mentioned in the table 1.

\section{Procedure for culture preparation and formulation}

Bacterial antogonists (Bacillus subtilis-KK9A, Brevibacillus borstelensis-BK-6, Brevibacillus sp-PM-2A and Lysinibacillus xylanilyticus- VK-6B) were grown in the nutrient broth by incubating at $30^{\circ} \mathrm{C}$ with 150 rpm for $72 \mathrm{hrs}$. Further, cultures were harvested by repeated centrifugation at 8,000 rpm for $20 \mathrm{~min}$ at $4^{\circ} \mathrm{C}$ in sterile distilled water. Finally, the spore pellet was resuspended in sterile Nutrient broth and used as active material in different formulations. The final spore titer was adjusted to $\geq 10^{8}$ $\mathrm{CFU} / \mathrm{ml}$.

The pellets of bacterial antagonists were mixed with all carrier material listed below in 1:3 ratio for preparation of powder formulation. However, for preparing $100 \mathrm{~g}$ of powder formulation $1 \%$ carboximethyl cellulose (CMC) as binder, $0.1 \%$ tritan $-\mathrm{x}$ as stabilizer was added and mixed thoroughly under laminar air flow chamber and packed in 120 guage polythene covers and stored at room temperature.

\section{Enumeration of CFU}

The shelf life was determined by enumerating the population of bacterial antagonists by serial dilution plate method using nutrient agar medium.

The dilution was prepared by taking $1 \mathrm{~g}$ of formulation in $9 \mathrm{ml}$ sterilized water, shaken well on orbital spinax for $5 \mathrm{~min}$ and further diluted to get the final dilution of $10^{7}$. From these dilutions of $0.1 \mathrm{ml}$ was taken and spread on nutrient agar plates. 
These plates were incubated at $30^{\circ} \mathrm{C}$ and observed regularly for the appearance of microbial colonies.

The population $(\mathrm{cfu} / \mathrm{g})$ was counted by average number of colonies (average of $10^{5}$ $10^{6}$ and $10^{7}$ ) developed in each treatment.

\section{Results and Discussion}

\section{Shelf life of bio-agents in solid formulation}

To prepare powder formulation of Bacillus subtilis, Brevibacillus borstelensis, Brevibacillus sp. and Lysinibacillus xylanilyticus, seven different types of inorganic carrier materials viz., bentonate, kaolin, perlite, phytosil, talc, vermiculite and zeolite were used. The inorganic carrier material like vermiculite supported the highest number of colonies of all the four bioagents up to 90days followed by zeolite, kaolin, perlite, talc, bentonate and phytosil in the order.

The shelf life of powder formulation of all the four bio-agents was checked at fifteen days interval. On the initial day, all the powder formulation recorded highest number of colonies which were on par with each other but the colonies count showed a declining trend from first day onwards up to three months as presented in tables 2-6 and figure 1 .

\section{Bacillus subtilis}

The results on shelf life of Bacillus subtilis in solid formulation is presented in the table 2 . Among all the carrier material tested, vermiculite based formulation was recorded highest number of colonies (8.00) on $90^{\text {th }}$ day.

In which the initial colony count was 37.00. Later the number of colonies were continued to decline and recorded $31.00,22.67,18.00$, 14.00 and 11.00 colonies at $15^{\text {th }}, 30^{\text {th }}, 45^{\text {th }}$, $60^{\text {th }}$ and $75^{\text {th }}$ day respectively. However, zeolite found next best carrier material which recorded 5.00 colonies after $90^{\text {th }}$ day with the initial count of 36.33 . Whereas kaolin, perlite and bentonate were found on par which recorded the number of colonies of 4.00, 4.00 and 2.00 respectively on $90^{\text {th }}$ day with the initial count of $35.33,35.67$ and 36.67 colonies. In case of talc based formulation the number of colonies were 2.33 on $90^{\text {th }}$ day with initial count of 36.33 colonies. However phytosil recorded least number of colonies (1.33) at $90^{\text {th }}$ day and the initial count of 35.67 colonies.

The highest per cent survival $(21.60 \%)$ of Bacillus subtilis was recordedat $90^{\text {th }}$ day in vermiculite followed by zeolite $(13.80 \%)$, kaolin $(11.30 \%)$, perlite $(11.20 \%)$, talc $(6.40$ $\%)$, bentonate $(5.50 \%)$ and phytosil $(3.70 \%)$.

\section{Brevibacillus borstelensis}

The shelf life of Brevibacillus borstelensis in different solid carrier materials were recorded and presented in the table 3. All the treatments are found significant with the number of colonies at $90^{\text {th }}$ day. The highest number of colonies (15.00) was recorded in case of vermiculite followed by zeolite 8.33 which were recorded the initial count of 32.33 and 32.00 respectively. However the number of colonies was declined to 28.33, 26.00, $24.00,20.00$ and 16.00 in case of vermiculite formulation at $15^{\text {th }}, 30^{\text {th }}, 45^{\text {th }}, 60^{\text {th }}$ and $75^{\text {th }}$ day respectively.

The lowest number of colonies (1.00) was recorded in case of phytosil at $90^{\text {th }}$ day. However the colony count was recorded 7.00, 4.67, 2.67 and 2.00 in case of kaolin, perlite, talc and bentonate respectively at $90^{\text {th }}$ day. Among all the seven carrier material, vermiculite recorded the highest per cent survival $(46.30 \%)$ of Brevibacillus borstelensis followed by zeolite (26.03\%), 
kaolin $(22.34 \%)$. However the least per cent survival of colonies $(3.15 \%)$ was recorded in phytosil after 90days.

\section{Brevibacillus sp.}

In case of Brevibacillus sp. the shelf life in solid formulation with different carrier material was studied and recorded in the table 4. The results revealed that vermiculite supported well for the survival of the culture and recorded highest number of colonies (9.00) with the initial count of 29.67 colonies and gradually reduced to $23.00,21.00,18.00$, 14.00 and 11.00 on $15^{\text {th }}, 30^{\text {th }}, 45^{\text {th }}, 60^{\text {th }}$ and $75^{\text {th }}$ day respectively. The zeolite found next best carrier material to support the growth of the bio-agent which recorded the number of colonies count of 6.00 at $90^{\text {th }}$ day with the initial count of 29.33 colonies. Among all seven carrier material tested, the phytosil recorded least number of colonies 1.67 at $90^{\text {th }}$ day. However the number of colonies was reduced gradually in all the tested carrier materials at each stage of observation.

The highest per cent survival $(30.30 \%)$ at $90^{\text {th }}$ day was recorded in case of vermiculite followed by zeolite $(20.50 \%)$, kaolin $(18.60$ $\%)$, perlite $(15.70 \%)$, talc $(7.00 \%)$ and bentonate $(6.90 \%)$. Whereas the least per cent colony survival $(5.60 \%)$ was observed in phytosil.

Table.1 Physico-chemical properties of solid carrier materials

\begin{tabular}{|l|l|l|l|l|l|}
\hline \multicolumn{1}{|c|}{$\begin{array}{c}\text { Carrier } \\
\text { material name }\end{array}$} & \multicolumn{1}{|c|}{ Composition } & $\begin{array}{c}\text { Particle } \\
\text { size (mm) }\end{array}$ & \multicolumn{1}{|c|}{ Color } & pH & \multicolumn{1}{|c|}{ Source } \\
\hline Bentonate & $\mathrm{Mg}_{3} \mathrm{SiO}_{10}(\mathrm{OH})_{2}$ & 0.032 & Light brown & 7.20 & Green field Eco, Solutions. Pvt. Ltd \\
\hline Kaolin & $\mathrm{Al}_{2} \mathrm{O}_{3} 4 \mathrm{SiO}_{2} \mathrm{H}_{2} \mathrm{O}$ & 0.081 & Dull white & 6.80 & $\begin{array}{l}\text { BCRL, Rajanakunte, Yelahnka, } \\
\text { Bangalore }\end{array}$ \\
\hline Perlite & $\mathrm{SiO}_{2} \mathrm{Al}_{2} \mathrm{O}_{3} \mathrm{Fe}_{2} \mathrm{O}_{3}$ & 1.41 & White crystals & 7.10 & Green field Eco, Solutions. Pvt. Ltd \\
\hline Phytosil & $\left(\mathrm{AlSi}_{3} \mathrm{O}_{4}\right.$ & 0.021 & $\begin{array}{l}\text { Creamish } \\
\text { white powder }\end{array}$ & 6.70 & $\begin{array}{l}\text { BCRL, Rajanakunte, Yelahnka, } \\
\text { Bangalore }\end{array}$ \\
\hline Talc & $\begin{array}{l}\mathrm{SiO}_{2} \mathrm{Al}_{2} \mathrm{O}_{3} \mathrm{Fe}_{2} \mathrm{O}_{3} \mathrm{Na}_{2} \mathrm{OK}_{2} \\
\mathrm{OCaO}^{2}\end{array}$ & 0.051 & White powder & 6.20 & $\begin{array}{l}\text { BCRL, Rajanakunte, Yelahnka, } \\
\text { Bangalore }\end{array}$ \\
\hline Vermiculite & $\mathrm{MgFe}^{+2}\left[\left(\mathrm{AlSi}_{4}\right) \mathrm{O}_{10}\right]$ & 2.00 & Greyish brown & 7.80 & Green field Eco, Solutions. Pvt. Ltd \\
\hline Zeolite & $\mathrm{SiO}_{2} \mathrm{Al}_{2} \mathrm{O}_{3} \mathrm{Na}_{2} \mathrm{O}$ & 1.41 & Faint brown & 6.71 & $\begin{array}{l}\text { Department of Soil Science, COH, } \\
\text { Bagalkot }\end{array}$ \\
\hline
\end{tabular}

Table.2 Shelf life of Bacillus subtilis in different solid formulation

\begin{tabular}{|c|c|c|c|c|c|c|c|c|c|}
\hline \multirow{2}{*}{$\begin{array}{r}\text { Sl. } \\
\text { No. }\end{array}$} & \multirow[b]{2}{*}{ Shelf life } & \multicolumn{7}{|c|}{$\left(\mathrm{x} 10^{7}\right) \mathrm{CFU} / \mathrm{g}$ of formulation } & \multirow[b]{2}{*}{ Survival \% } \\
\hline & & 0 day & $15^{\text {th }}$ day & $30^{\text {th }}$ day & $45^{\text {th }}$ day & $60^{\text {th }}$ day & $75^{\text {th }}$ day & $90^{\text {th }}$ day & \\
\hline 1 & Bentonate & 36.67 & 13.67 & 8.33 & 8.00 & 4.67 & 3.33 & 2.00 & 5.50 \\
\hline 2 & Kaolin & 35.33 & 17.00 & 11.00 & 11.00 & 7.00 & 4.00 & 4.00 & 11.30 \\
\hline 3 & Perlite & 35.67 & 20.33 & 14.00 & 12.00 & 9.00 & 5.00 & 4.00 & 11.20 \\
\hline 4 & Phytosil & 35.67 & 8.67 & 6.33 & 6.67 & 3.00 & 1.67 & 1.33 & 3.70 \\
\hline 5 & Talc & 36.33 & 10.00 & 8.33 & 7.00 & 4.33 & 2.67 & 2.33 & 6.40 \\
\hline 6 & Vermiculite & 37.00 & 31.00 & 22.67 & 18.00 & 14.00 & 11.00 & 8.00 & 21.60 \\
\hline 7 & Zeolite & 36.33 & 25.00 & 20.00 & 15.00 & 11.00 & 7.00 & 5.00 & 13.80 \\
\hline \multirow{2}{*}{\multicolumn{2}{|c|}{ SEm \pm}} & & 0.65 & 0.59 & 0.55 & 0.60 & 0.49 & 0.56 & \\
\hline & & $\mathrm{NS}$ & 2.76 & 2.49 & 2.31 & 2.54 & 2.05 & 2.37 & \\
\hline
\end{tabular}


Table.3 Shelf life of Brevibacillus borstelensis in different solid formulations

\begin{tabular}{|c|c|c|c|c|c|c|c|c|c|}
\hline \multirow{2}{*}{$\begin{array}{r}\text { Sl. } \\
\text { No. }\end{array}$} & \multirow{2}{*}{ Shelf life } & \multicolumn{7}{|c|}{$\left(x 10^{7)}\right) \mathrm{CFU} / \mathrm{g}$ of formulation } & \multirow{2}{*}{ Survival \% } \\
\hline & & O day & $15^{\text {th }}$ day & $30^{\text {th }}$ day & $45^{\text {th }}$ day & $60^{\text {th }}$ day & $75^{\text {th }}$ day & $90^{\text {th }}$ day & \\
\hline 1 & Bentonate & 32.00 & 11.00 & 9.00 & 7.00 & 3.00 & 2.00 & 2.00 & 6.25 \\
\hline 2 & Kaolin & 31.33 & 21.33 & 19.00 & 17.00 & 11.00 & 8.33 & 7.00 & 22.34 \\
\hline 3 & Perlite & 32.00 & 18.33 & 16.67 & 13.33 & 9.00 & 4.33 & 4.67 & 14.50 \\
\hline 4 & Phytosil & 31.67 & 9.00 & 4.67 & 3.00 & 2.33 & 1.67 & 1.00 & 3.15 \\
\hline 5 & Talc & 31.33 & 14.67 & 12.00 & 10.33 & 6.33 & 4.33 & 2.67 & 8.52 \\
\hline 6 & Vermiculite & 32.33 & 28.33 & 26.00 & 24.00 & 20.00 & 16.00 & 15.00 & 46.30 \\
\hline 7 & Zeolite & 32.00 & 25.00 & 22.33 & 18.67 & 15.00 & 12.00 & 8.33 & 26.03 \\
\hline \multicolumn{2}{|r|}{ SEm \pm} & & 0.63 & 0.63 & 0.79 & 0.60 & 0.63 & 0.58 & \\
\hline \multicolumn{2}{|c|}{$\mathrm{CD}(0.01)$} & NS & 2.65 & 2.76 & 3.31 & 2.54 & 2.65 & 2.43 & \\
\hline
\end{tabular}

Table.4 Shelf life of Brevibacillus sp in different solid formulations

\begin{tabular}{|c|c|c|c|c|c|c|c|c|c|}
\hline \multirow{2}{*}{$\begin{array}{l}\text { Sl. } \\
\text { No. }\end{array}$} & \multirow{2}{*}{ Shelf life } & \multicolumn{7}{|c|}{$\left(\times 10^{7}\right) \mathrm{CFU} / \mathrm{g}$ of formulation } & \multirow{2}{*}{$\begin{array}{l}\text { Survi } \\
\text { val } \%\end{array}$} \\
\hline & & 0 day & $15^{\text {th }}$ day & $30^{\text {th }}$ day & $45^{\text {th }}$ day & $60^{\text {th }}$ day & $75^{\text {th }}$ day & $90^{\text {th }}$ day & \\
\hline 1 & Bentonate & 29.00 & 9.00 & 7.67 & 6.00 & 5.67 & 3.67 & 2.00 & 6.90 \\
\hline 2 & Kaolin & 28.67 & 14.33 & 13.00 & 11.00 & 8.00 & 7.67 & 5.33 & 18.60 \\
\hline 3 & Perlite & 27.67 & 12.33 & 10.67 & 10.67 & 6.00 & 6.67 & 4.33 & 15.70 \\
\hline 4 & Phytosil & 29.67 & 4.33 & 3.67 & 2.67 & 2.33 & 1.67 & 1.67 & 5.60 \\
\hline 5 & Talc & 28.33 & 6.33 & 6.00 & 5.33 & 5.00 & 3.67 & 2.00 & 7.00 \\
\hline 6 & Vermiculite & 29.67 & 23.00 & 21.00 & 18.00 & 14.00 & 11.00 & 9.00 & 30.30 \\
\hline 7 & Zeolite & 29.33 & 21.00 & 18.00 & 15.67 & 10.67 & 9.00 & 6.00 & 20.50 \\
\hline & SEm \pm & & 0.70 & 0.65 & 0.67 & 0.62 & 0.68 & 0.69 & \\
\hline & $\mathrm{CD}(0.01)$ & NS & 2.95 & 2.76 & 2.81 & 2.60 & 2.86 & 2.91 & \\
\hline
\end{tabular}

Table.5 Shelf life of Lysinibacillus xylanilyticus in different solid formulations

\begin{tabular}{|c|c|c|c|c|c|c|c|c|c|}
\hline \multirow{2}{*}{$\begin{array}{l}\text { Sl. } \\
\text { No. }\end{array}$} & \multirow{2}{*}{ Shelf life } & \multicolumn{7}{|c|}{$\left(\mathrm{x10}^{7)}\right) \mathrm{CFU} / \mathrm{g}$ of formulation } & \multirow{2}{*}{$\begin{array}{c}\text { Survival } \\
\%\end{array}$} \\
\hline & & O day & $15^{\text {th }}$ day & $30^{\text {th }}$ day & $45^{\text {th }}$ day & $60^{\text {th }}$ day & $75^{\text {th }}$ day & $90^{\text {th }}$ day & \\
\hline 1 & Bentonate & 22.00 & 6.00 & 5.00 & 3.67 & 3.00 & 2.67 & 2.33 & 10.60 \\
\hline 2 & Kaolin & 22.00 & 15.00 & 14.00 & 10.33 & 10.33 & 8.00 & 5.00 & 22.70 \\
\hline 3 & Perlite & 22.67 & 10.00 & 8.67 & 7.00 & 5.00 & 4.67 & 4.33 & 19.10 \\
\hline 4 & Phytosil & 23.00 & 7.00 & 5.00 & 4.33 & 3.67 & 3.33 & 2.33 & 10.10 \\
\hline 5 & Talc & 21.00 & 9.33 & 7.67 & 6.00 & 5.00 & 4.00 & 3.33 & 15.90 \\
\hline 6 & Vermiculite & 23.67 & 17.33 & 16.67 & 13.00 & 11.00 & 9.00 & 6.67 & 28.20 \\
\hline 7 & Zeolite & 23.00 & 12.00 & 11.33 & 9.00 & 7.33 & 6.33 & 5.67 & 24.60 \\
\hline & SEm \pm & & 0.64 & 0.91 & 0.65 & 0.62 & 0.70 & 0.85 & \\
\hline & $\mathrm{CD}(0.01)$ & NS & 2.70 & 3.82 & 2.76 & 2.60 & 2.95 & 3.56 & \\
\hline
\end{tabular}


Table.6 Shelf life of consortium in different solid formulations

\begin{tabular}{|c|c|c|c|c|c|c|c|c|c|}
\hline $\begin{array}{c}\text { Sl. } \\
\text { No. }\end{array}$ & \multirow{2}{*}{ Shelf life } & \multicolumn{9}{|c|}{$\mathbf{( x 1 0}^{\mathbf{7}}$ ) CFU/g of formulation } & Survival \\
\cline { 3 - 10 } \\
\cline { 3 - 10 } & & $\mathbf{0}$ day & $\mathbf{1 5}^{\text {th }} \mathbf{d a y}$ & $\mathbf{3 0}^{\text {th }} \mathbf{d a y}$ & $\mathbf{4 5}^{\text {th }} \mathbf{d a y}$ & $\mathbf{6 0}^{\text {th }}$ day & $\mathbf{7 5}^{\text {th }}$ day & $\mathbf{9 0}^{\text {th }}$ day & \% \\
\hline 1 & Bentonate & 44.33 & 17.67 & 15.00 & 11.00 & 8.67 & 3.67 & 1.67 & 3.80 \\
\hline 2 & Kaolin & 46.33 & 29.33 & 27.00 & 20.00 & 16.67 & 9.00 & 7.00 & 15.10 \\
\hline 3 & Perlite & 45.67 & 26.33 & 22.00 & 17.00 & 12.67 & 7.00 & 4.00 & 8.80 \\
\hline 4 & Phytosil & 46.00 & 11.00 & 9.00 & 7.00 & 6.00 & 2.00 & 1.33 & 2.90 \\
\hline 5 & Talc & 46.33 & 18.33 & 19.67 & 15.00 & 10.67 & 5.00 & 2.67 & 5.80 \\
\hline 6 & Vermiculite & 46.67 & 41.00 & 42.33 & 35.00 & 29.67 & 25.00 & 15.00 & 32.10 \\
\hline 7 & Zeolite & 45.33 & 36.67 & 31.33 & 27.00 & 22.00 & 12.33 & 11.00 & 24.30 \\
\hline & & 0.86 & 0.58 & 0.58 & 0.86 & 0.60 & 0.53 & \\
\hline & SEm \pm & ND $(0.01)$ & 3.64 & 2.43 & 2.43 & 3.64 & 2.54 & 2.25 & \\
\hline
\end{tabular}

Fig.1 Shelf life of bioagents in different solid formulations

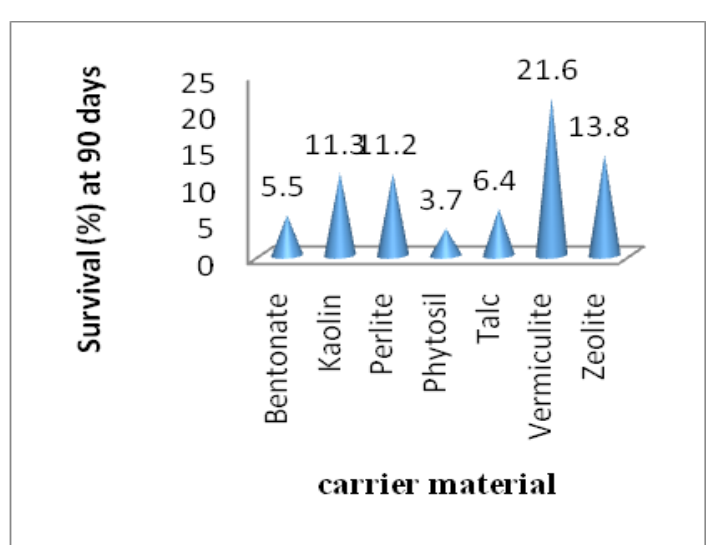

1a. Bacillus subtilis

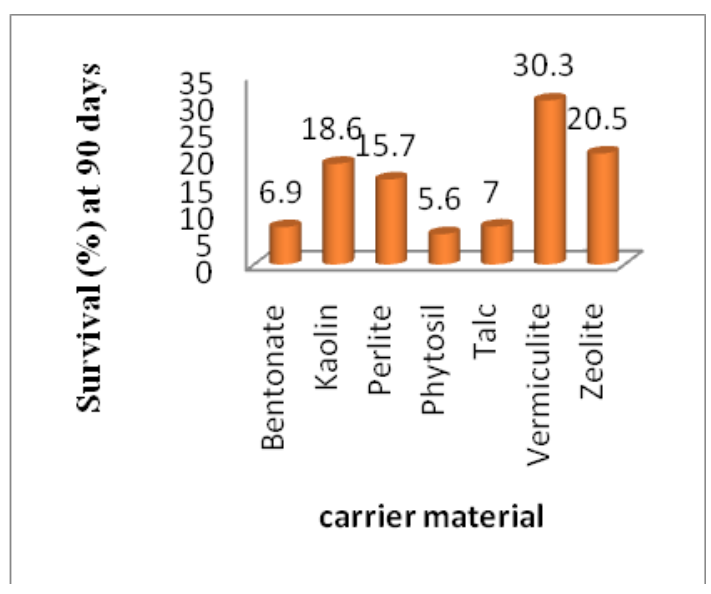

1c. Brevibacillus sp

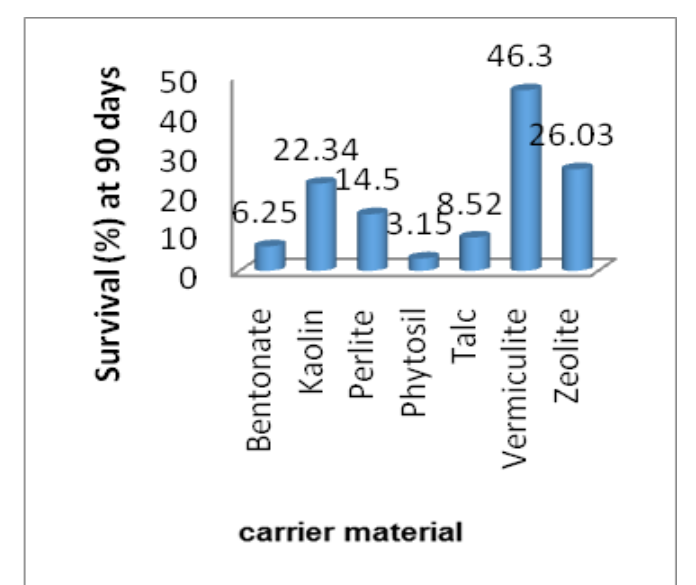

1b. Brevibacillus bostelensi

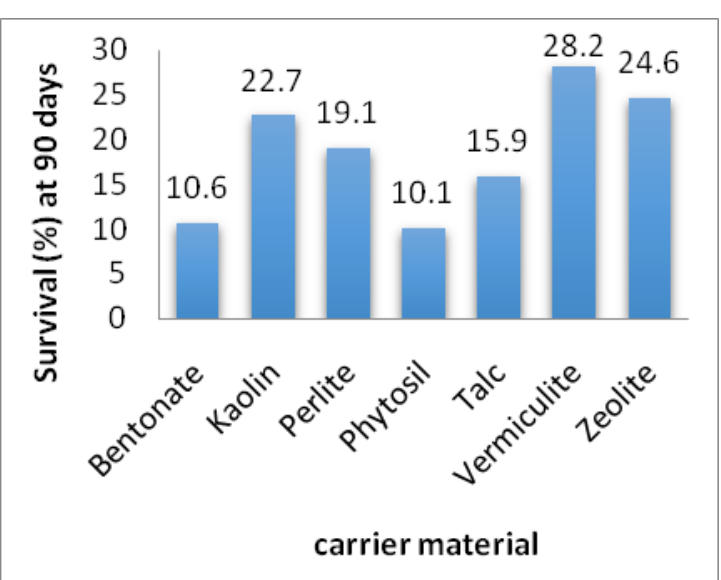

1d. Lysinibacillus xylenticus 


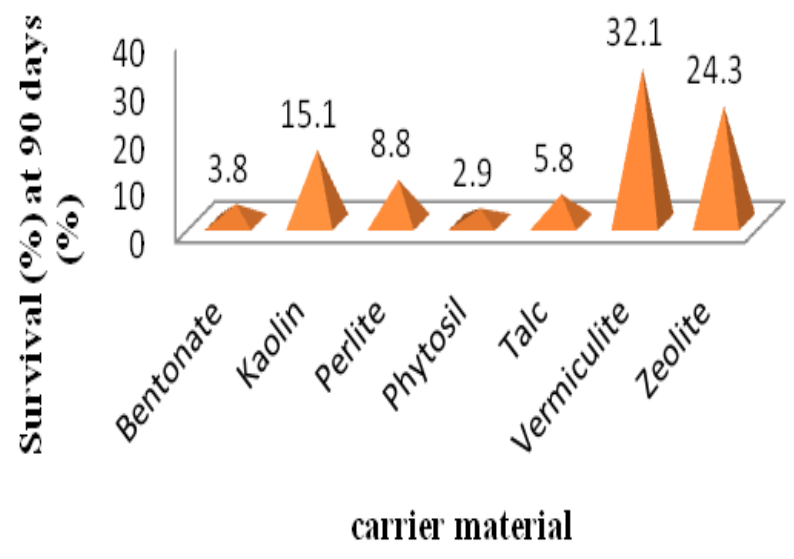

\section{1e. Consortium}

\section{Lysinibacillus xylanilyticus}

The results of shelf life in different solid carrier material w.r.t Lysinibacillus xylanilyticus is presented in table 5 .

Among seven carrier material tested, vermiculite recorded highest number of colonies of (6.67) at $90^{\text {th }}$ day and found on par with zeolite (5.67), kaolin (5.00)perlite (4.33). The reduction in the number of colonies was gradual at each stage of observation. Where the vermiculite recorded 17.33, 16.67, 13.00, 11.00 and 9.00 at $15^{\text {th }}, 30^{\text {th }}, 45^{\text {th }}, 60^{\text {th }}$ and $75^{\text {th }}$ day respectively.

However the phytosil and bentonate recorded least number of colonies (2.33) at $90^{\text {th }}$ day with the initial colony count of 23.00 and 22.00 respectively.

Among the carrier material tested vermiculite recorded highest per cent survival $(28.20 \%)$ of colonies followed by zeolite $(24.60 \%)$ and kaolin $(22.70 \%)$. Whereas phytosil recorded least per cent survival (10.1\%) after 90 days.

\section{Consortium}

The same trend has been observed with regard to consortium consisting of above said all the four bio-agents. The results related to the shelf life of consortium in different solid material are presented in the table 6 .

The results revealed that the vermiculite found significantly superior to all the treatments in extending the shelf life of consortium with highest number of colonies $(15.00)$ at $90^{\text {th }}$ day which recorded initial count of 46.67. However at each stage of observation, the number of colonies was reduced to $41.00,42.33,35.00,29.67$ and 25.00 at $15^{\text {th }}, 30^{\text {th }}, 45^{\text {th }}, 60^{\text {th }}$ and $75^{\text {th }}$ day respectively.

The zeolite found the next best treatment with 11.00 colonies at $90^{\text {th }}$ day and initial count of 45.33. Among all the treatments phytosil supported least for the growth of consortium which recorded 1.33 colonies at $90^{\text {th }}$ day.

The per cent survival of consortium at $90^{\text {th }}$ day was recorded highest $(32.10 \%)$ in case of vermiculite, whereas in zeolite it was 24.30 per cent and kaolin with 15.10 per cent however, the phytosil recorded least per cent survival $(2.90 \%)$ of consortium after 90 days.

Data presented in tables 2-6 reveals that, the highest number of colonies of Bacillus subtilis, Brevibacillus borstelensis, 
Brevibacillus sp and Lysinibacillus xylanilyticus, was observed by vermiculite based formulation of all four bio-agents and consortium when checked at fifteen days interval up to three months. This is followed by zeolite, kaolin, perlite, talc, bentonite, phytosil in the order.

However in phytosil based formulation least survival per cent of bio-agents from the day first to end of $90^{\text {th }}$ day and recorded 5.60, $10.10,3.15,3.70,2.90$ colonies respectively in solid formulations.

The vermiculite having larger particle size $(2 \mathrm{~mm})$ and slightly alkaline $\mathrm{pH}$ (7.80) when compared to other carrier materials followed by zeolite, supported to get highest number of colonies as these four bio-agents are of aerobic in nature and required neutral to alkaline $\mathrm{pH}$ (7-8) for their profused growth. Similar carrier material was used by Kloepper and Schroth (1981) for powder formulations of the $B$. subtilis recorded that it can survive in vermiculite and kaolin formulations up to 45 days at room temperature.

This is in accordance with the findings of Ruthvan (1984), who indicated porous materials with a hydrophilic surface such as zeolite and kaolin clay minerals are effective in trapping water inside the micropores and hence, the water needed for the germination of spores in these carrier-endospore formulation might had been physically separated from the spores.

Whereas Carrera et al., 2007 resulted that spores in perlite formulations where water is absorbed in the large pores and open channels were in contact with enough water to be germinated and hence proliferated. That is, pores in perlite were large enough to be penetrated by spores and could have actually acted as a water reservoir for the spores that came in contact with. This is in accordance to the observation that once the dormancy was broken, perlite II with larger pores $(8 \mu \mathrm{m})$ was more effective in stimulating the proliferation of the vegetative cells than perlite I with smaller pore size $(3.7 \mu \mathrm{m})$.

Amer and Utkhede (2000) were formulated the Bacillus subtilis and Pseudomonas putida using various carrier material such as vermiculite, talc, kaolin, and peat moss. In all carrier formulations, $B$. subtilis strain BACT0 survived up to 45 days, the populations $B$. subtilis strain BACT-0 were significantly higher in vermiculite, kaolin, and bacterial broth carriers compared with other carriers.

The objective of the study which was to find the best carriers for bacterial bio-agents and consortium were accomplished successfully with vermiculite still being a more superior carrier material as compared to zeolite, kaolin, perlite, talc, bentonite, phytosil. It is concluded that vermiculite performed better for formulation of Bacillus subtilis, Brevibacillus borstelensis, Brevibacillus sp. and Lysinibacillus xylanilyticus as it supports highest viable population up to 3 months.

\section{References}

Amer, G.A., and Utkhede, R. S., 2000. Development of formulations of biological agents for management of root rot of lettuce and cucumber. Journal of Microbiology, 46: 809-816.

Carrera, M., Zandomeni R.O., Fitsgibbon J and Sagripanti J., 2007.Difference between the spore sizes of Bacillus antracis and other Bacillus species. Journal of Applied Micrbiology, 102:303-312

Cook, R.J., and Baker, K. F., 1983. The nature and practice of biological control of plant pathogens. APS Press, St. Paul, USA, pp. 539.

Harman, G.E., 1991. Seed treatment for 
biological control of plant diseases. Crop. Protection. 10:166-171.

Hermosa, R., Viterbo, A., Chet, I and Monte,

E. 2012. Plant beneficial effects of Trichoderma and of its genes. Microbiology, 158: 17-25.

Kloepper, J. W., and Schroth, M. N. 1981. Development of powder formulations of Rhizobacteria for inoculation of potato seed pieces. Phytopathology, 71: 590 592.

Ramesh, I., 2015. Biological management of Xanthomonasaxonopodis pv. punicae (Hingorani and Singh) Vauterin et al., causing bacterial blight of punica granatum L.. M.Sc Thesis, University of Horticultural Sciences, Bagalkot.
Karnataka.

Ruthvan, D.M., 1984. Principles of adsorption and adsorption processes. Wiley, New York, pp 1-61.

Warriner, K., and W.M. Waites 1999. Enhanced sporulation in Bacillus subtilis grown on medium containing glucose: ribose. Letters in Applied Microbiology. 29: 97-102.

Yenjerappa, S.T., Nargund, V. B., Byadagi, A. S., Ravikumar, M. R., Mokashi, A. N. and Basavana G. K., 2013, Biological management of bacterial blight of pomegranate caused by Xanthomonas axonopodis pv. punicae. Karnataka J. Agric. Sci., 26(4): 561562.

\section{How to cite this article:}

Jayasudha, S.M., K.C. Kirankumar, Eranna Rajashekhara and Rudresh. 2017. Evaluation of Different Carrier Materials for Development of Bacterial Bio-Control Agents Formulations with Enhanced Shelf - Life. Int.J.Curr.Microbiol.App.Sci. 6(9): 1145-1153. doi: https://doi.org/10.20546/ijcmas.2017.609.138 